\title{
Erratum
}

\section{For Women Only? Gender Quotas and Intersectionality in France- ERRATUM}

Éléonore Lépinard

doi:10.1017/S1743923X13000251, Published by Cambridge University Press, 2 August 2013.

We regret that the originally published paper (Lépinard, 2013) did not contain the correct author biography.

We apologize for this oversight and reproduce the author's correct biography below:

\section{THE CORRECTION}

From page 295:

Éléonore Lépinard is Associate Professor of Gender Studies at Université de Lausanne, Lausanne, Switzerland: eleonore.lepinard@unil.ch

\section{REFERENCE}

Éléonore Lépinard. 2013. "For Women Only? Gender Quotas and Intersectionality in France" in Politics \& Gender 9 (3): 276-298.

Published by Cambridge University Press 1743-923X/13 \$30.00 for The Women and Politics Research Section of the American Political Science Association.

(C) The Women and Politics Research Section of the American Political Science Association, 2013

doi:10.1017/S1743923X13000421 